\title{
Rzeczpospolita w litewskich instrukcjach sejmikowych w latach 1587-1648. Próba analizy terminologicznej
}

Artykuł poświęcono analizie pojęcia rzeczpospolita w litewskich instrukcjach sejmikowych. Zgadzając się z Ewą Bem-Wiśniewską, iż ,język stosowany przez dane społeczeństwo odzwierciedla jego struktury"', autor uważa, że język jest jedną z ważniejszych płaszczyzn, w których przejawia się świadomość narodowa lub społeczna, a badania nad językiem (tak systemem pojęć, jak i retoryką) źródeł historycznych mogą wnieść nowe spojrzenie na zagadnienia, którymi zainteresowana jest również historia prawa. Szkic nie rości sobie pretensji do wyczerpania tematu, raczej wskazuje zagadnienia, mogące być przedmiotem dalszych badań.

Historyk dokonujący takich interpretacji spotyka się z niejednym problemem. Wspomniana już E. Bem-Wiśniewska wskazała, że „,badane hasła niosą ze sobą różne poziomy semantyczne"2. W interpretacji tych zjawisk nie da się - niestety - uciec od arbitralności. „Ani obszerny cytat, ani szeroki kontekst nie zawsze dają bowiem pewność, w jakim znaczeniu badany termin występuje"3. Mając świadomość tych trudności, zrezygnowano w niniejszej pracy z przedstawienia klasyfikacji tej terminologii na rzecz rozważań o charakterze typologicznym.

W rozważaniach skorzystano zarówno z metod statystycznych - przy obliczaniu frekwencji występowania wyrazów, jak i z metody egzemplifikacyjnej, dającej możliwość zapoznania się z kontekstem, w jakim badane zwroty występują. Przy badaniu frekwencji wyrazów pomocne okazały się zarówno

${ }^{1}$ E. Bem-Wiśniewska, Funkcjonowanie nazwy „Polska” w języku czasów nowożytnych, Warszawa 1998, s. 8.

${ }^{2}$ Autorka wyróżnia (zaznaczając jednocześnie, że schemat ów ma charakter przede wszystkim teoretyczny) cztery rodzaje znaczeń: ujawnione dla autora i dla czytelnika; ujawnione dla autora, nie rozpoznane przez czytelnika; rozpoznawalne dla czytelnika, użyte przez autora bezwiednie; nieujawnione zarówno dla czytelnika, jak i dla autora; ibid., s. 58-59.

${ }^{3}$ K. Mazur, W strone integracji z Korona. Sejmiki Wolynia i Ukrainy w latach 1569-1648, Warszawa 2006, s. 227-228. 
liczby bezwzględne, jak i częstość użyć, wyrażona za pomocą liczby użyć danego wyrazu w instrukcji oraz liczby użyć na stronę rękopisu.

Za podstawę źródłową analizy przyjęto 141 instrukcji sejmików z obszaru Wielkiego Księstwa Litewskiego z lat 1587-1648, poczynając od sejmu koronacyjnego Zygmunta III Wazy. W rozważaniach uwzględniono rękopiśmienne zbiory Archiwum Głównego Akt Dawnych w Warszawie, Biblioteki Polskiej Akademii Umiejętności i Polskiej Akademii Nauk w Krakowie, Biblioteki Czartoryskich w Krakowie oraz Rosyjskiej Biblioteki Narodowej w Sankt-Petersburgu.

W celu pokazania dynamiki przemian obserwowanych zjawisk okres 1587-1648 podzielono na podokresy, odpowiadające w przybliżeniu kolejnym dziesięcioleciom: 1587-1600, 1601-1610, 1611-1620, 1621-1630, 1631-1640 i 1641-1648. Liczbę instrukcji wykorzystanych w kolejnych podokresach przedstawiono w Tabeli 1.

Tabela 1. Liczba instrukcji sejmikowych w kolejnych latach

\begin{tabular}{c|c}
\hline Lata & Liczba instrukcji \\
\hline $1587-1600$ & 17 \\
\hline $1601-1610$ & 14 \\
\hline $1611-1620$ & 31 \\
\hline $1621-1630$ & 22 \\
\hline $1631-1640$ & 32 \\
\hline $1641-1648$ & 25 \\
\hline Ogółem 1587-1648 & 141 \\
\hline
\end{tabular}

Należy zauważyć, że z biegiem czasu zebrana na sejmikach szlachta miała tendencję do pisania coraz dłuższych instrukcji. Zjawisko to ilustruje Tabela 2, przedstawiająca średnią liczbę stron rękopisu w kolejnych okresach.

Tabela 2. Długość instrukcji w kolejnych latach

\begin{tabular}{c|c}
\hline Lata & Średnia liczba stron rękopisu \\
\hline $1587-1600$ & 4,5 \\
\hline $1601-1610$ & 4,93 \\
\hline $1611-1620$ & 5,42 \\
\hline $1621-1630$ & 4,64 \\
\hline $1631-1640$ & 5,56 \\
\hline $1641-1648$ & 7,4 \\
\hline Ogółem $1587-1648$ & 5,53 \\
\hline
\end{tabular}


Ze względu na różną liczbę instrukcji w poszczególnych okresach, jak i różną ich długość uzasadnione wydaje się wykorzystanie nie tylko liczb bezwzględnych, ale też następujących przeliczników: liczby użyć na instrukcję (w przypadku rzadziej pojawiających się terminów) oraz liczby użyć na stronę rękopisu (w przypadku częściej wykorzystywanych pojęć). Należy mieć jednak świadomość, że i te wskaźniki nie są całkowicie obiektywne. Rękopisy charakteryzują się wszak różnym charakterem pisma i różną długością tekstu zamieszczonego na jednej stronie źródła. Nie są to więc wskaźniki całkowicie porównywalne, ich wykorzystanie pozwala jednak dostrzec pewne interesujące tendencje dotyczące języka i retoryki litewskich instrukcji sejmikowych.

Należy wspomnieć, iż poza nawias obliczeń statystycznych wyłączono instrukcję wiłkomierską z 1600 roku$^{4}$. Powody, które przemawiały za takim rozwiązaniem, a także krótką charakterystykę tej instrukcji przedstawiono w końcowej części artykułu.

Podkreślmy także, że ze względu na charakter instrukcji sejmikowych jako źródła historycznego, jak i na sam fakt rozpatrywania retoryki i języka tylko jednego, ściśle określonego typu źródła (przez co nie może być mowy o reprezentatywności źródeł w odniesieniu do badanego okresu), nasze rozważania nie pretendują do wyciągania ogólnych wniosków dotyczących postaw szlachty litewskiej, wyrażanych w używanym przez nią języku i retoryce.

Pojęcie rzeczypospolitej jest jednym z najważniejszych pojęć polskiej terminologii politycznej czasów nowożytnych. Wywodzące się z łacińskiej terminologii ustrojowej, będące często przedmiotem naśladowania jako niedościgły wzór organizacji państwa, wywarło „znamienny, jednoznaczny wpływ na świadomość polityczną społeczeństwa, jak i na kształt państwa"5. Niestety, w odróżnieniu od niektórych innych pojęć polskiego języka politycznego $^{6}$, termin rzeczpospolita nie doczekał się szczegółowych opracowań czy prób systematyzacji ${ }^{7}$.

Termin rzeczpospolita (wraz z łacińskim odpowiednikiem, tj. respublica) jest pojęciem najczęściej występującym w instrukcjach sejmikowych, będących przedmiotem niniejszej analizy. We wszystkich źródłach występuje on

${ }^{4}$ Rossijskaja Nacionalnaja Biblioteka w Sankt-Petersburgu, Otdieł Rukopisiej, f. 971: Polskije awtografy iz sobranija P.P. Dubrowskogo, inw. 2 [dalej: RNB], awt. 133, k. 121-127.

${ }^{5}$ E. Bem-Wiśniewska, Funkcjonowanie..., s. 168.

${ }^{6}$ Nazwa Polska była przedmiotem wielokrotnie cytowanej tu pracy E. Bem-Wiśniewskiej (Funkcjonowanie...); ta sama autorka przedmiotem swoich badań uczyniła też pojęcie ojczyzny: E. Bem, Termin ,ojczyzna” w literaturze XVI i XVII wieku. Refleksje o języku, „Odrodzenie i Reformacja w Polsce", t. XXXV, R. 1989, s. 131-156; terminowi ojczyzna poświęcona została też praca B. Otwinowskiej, Wyraz ,ojczyzna” na przestrzeni życia i twórczości Jana Kochanowskiego, „Poezja”, R. 1980, nr 8-9; ostatnio terminem tym, jak i pojęciami państwa i narodu, zajęła się: J. Legomska, Państwo, naród, ojczyzna w dawnej polszczyźnie. Leksykalno-semantyczny opis pojęć, Katowice 2010.

${ }^{7}$ Nie mogą spełnić tej roli rozważania E. Bem-Wiśniewskiej, mające charakter krótkiej konfrontacji z terminem Polska; por. E. Bem-Wiśniewska, Funkcjonowanie..., s. 168-171. 
łącznie aż 1653 razy. Trudność w jego interpretacji polega na wieloznaczności, dostrzeżonej już przez Samuela Bogumiła Lindego. Wyróżnił on następujące znaczenia tego pojęcia:

- spólna rzecz, społeczność (die Gemeinschaft);

- rząd, państwo, stan (der Staat);

- stan polityczny państwa, w którym albo wszystek, albo część z ludu wybrana ma rząd i najwyższą władzę (die Republik) $)^{8}$.

E. Bem-Wiśniewska wyróżniła aż 15 typów znaczeń, spośród których szczególną uwagę poświęciła 5:

- państwo polsko-litewskie;

- władza, czyli sejm polski, ale też określenie posłów;

- określenie szlachty, czyli wspólnoty;

- symbol dla oznaczenia treści ideowych związanych z państwem polskim, szlachtą jako wspólnotą, z ustrojem demokracji szlacheckiej;

- formacja ustrojowa, typ rządów, sposób sprawowania władzy; znaczenie bliskie dzisiejszemu rozumieniu terminu ,republika" 9

Wieloznaczność ta nie jest jednak jedynym i najistotniejszym problemem interpretacyjnym tutaj spotykanym. Na gruncie przebadanych instrukcji wypada potwierdzić poczynione w stosunku do województwa kijowskiego, bracławskiego i wołyńskiego spostrzeżenie Karola Mazura:

niekiedy bardzo trudno jest ustalić, co w danym kontekście szlachta miała na myśli, mówiąc Rzeczpospolita. Wydaje się, że czasami obywatele ziem inkorporowanych nie musieli odróżniać znaczeń tego słowa i mogli rozumieć je zarówno jako państwo i sejm, państwo i wspólnotę albo sejm i wspólnotę ${ }^{10}$.

Rzeczywiście, w praktyce różnice między tymi znaczeniami mogły się zacierać, co więcej, dany wyraz mógł jednocześnie zawierać kilka z nich. Wydaje się więc, że stworzenie klasyfikacji znaczeń obciążone jest daleko idącym subiektywizmem i arbitralnością, brak bowiem narzędzi, za pomocą których można by rozwiać wątpliwości interpretacyjne i przyporządkować dane użycie do określonej grupy znaczeń. Raz jeszcze należy więc podkreślić typologiczny, a nie klasyfikacyjny charakter naszych rozważań.

${ }^{8}$ B. Linde, Stownik języka polskiego, T. 3, Warszawa 1812, s. 167-168.

${ }^{9}$ E. Bem-Wiśniewska, Funkcjonowanie..., s. 168-170; por. także H. Wisner, Rzeczypospolite szlachty litewskiej (schytek wieku XVI-pierwsza połowa XVII wieku), „Barok”, t. 13: 2006, nr 1 (25), s. 20; nie można więc zgodzić się z J. Dzięgielewskim, wedle którego słowo „Rzeczpospolita” zawsze oznacza państwo. W sformułowaniach ,, bez consensusu Rzeczypospolitej” czy in facie Reipublicae termin ten nie odnosi się do sejmu czy wspólnoty szlacheckiej, ale do stanów politycznych utożsamiajacych państwo. Bytby to zatem swoisty skrót myślowy podobny do używanych obecnie, gdy mówimy ,państwo”, a powinniśmy precyzyjnie powiedzieć ,, władza państwowa” bądź gdy stan duchowny, a nawet tylko episkopat określamy pojęciem Kościól; por. K. Mazur, op. cit., s. 255-256, przyp. 133.

${ }^{10}$ Ibidem, s. 229. 
Wskazane problemy, choć są przesłanką dla daleko idącej ostrożności, nie przekreślają jednak możliwości wysnucia wniosków. Dlatego też podjęto tu próbę egzemplifikacji wskazanych przez E. Bem-Wiśniewską kategorii znaczeń, poprzez przyporządkowanie im jednoznacznie dających się odczytać użyć. Podążając śladem K. Mazura, pominięto czwarte ze wskazanych przez badaczkę znaczeń, a więc „symbol dla oznaczenia treści ideowych”, które wydaje się najmniej uchwytnym i rodzącym najwięcej wątpliwości. Z powodu znacznych trudności interpretacyjnych - o czym poniżej, do pierwszego znaczenia, tj. państwo polsko-litewskie, dołączono też znaczenie państwo $w$ ogóle. W naszym ujęciu scharakteryzowane zostaną więc 3 znaczenia terminu rzeczpospolita. Będą to:

- państwo (w tym państwo polsko-litewskie);

- władza, czyli sejm Rzeczypospolitej, ale też określenie posłów;

- określenie szlachty, czyli wspólnoty.

Ujęcie takie jest niewątpliwie dalekie od systematyczności, pozostawia też znaczącą liczbę użyć nieprzyporządkowanych do określonego znaczenia. Jeszcze raz podkreślmy, że wysuwanie na podstawie niniejszego szkicu daleko idących wniosków byłoby obarczone znacznym ryzykiem.

Jak już wspomniano, termin rzeczpospolita w badanych instrukcjach występuje aż 1653 razy. W omawianym okresie frekwencja jego użycia przedstawia się następująco (Tabela 3).

Tabela 3. Użycie terminu rzeczpospolita w kolejnych latach

\begin{tabular}{c|c|c}
\hline Lata & Rzeczpospolita - ogólem & Rzeczpospolita na stronę rękopisu \\
\hline $1587-1600$ & 99 & 1,49 \\
\hline $1601-1610$ & 115 & 1,71 \\
\hline $1611-1620$ & 387 & 2,26 \\
\hline $1621-1630$ & 259 & 2,48 \\
\hline $1631-1640$ & 421 & 2,24 \\
\hline $1641-1648$ & 372 & 1,95 \\
\hline Ogółem 1587-1648 & 1653 & 2,09 \\
\hline
\end{tabular}

Dla czytelniejszego zobrazowania zachodzących zjawisk posłużmy się wykresem (Wykres 1), przedstawiającym współczynnik rzeczpospolita/stronę rękopisu w kolejnych okresach.

Nie wdając się na razie w szczegółowe rozważania znaczenia pojęcia rzeczypospolitej, warto już na tym etapie odnotować interesującą tendencję. W latach 1587-1630 stopniowo, acz wyraźnie, wzrasta liczba użyć tego terminu, z poziomu 1,49 do 2,48 na stronę rękopisu. W następnych latach mamy jednak do czynienia z pewnym spadkiem liczby użyć - do poziomu 
Wykres 1. Liczba użyć terminu Rzeczpospolita na stronę rękopisu w kolejnych latach

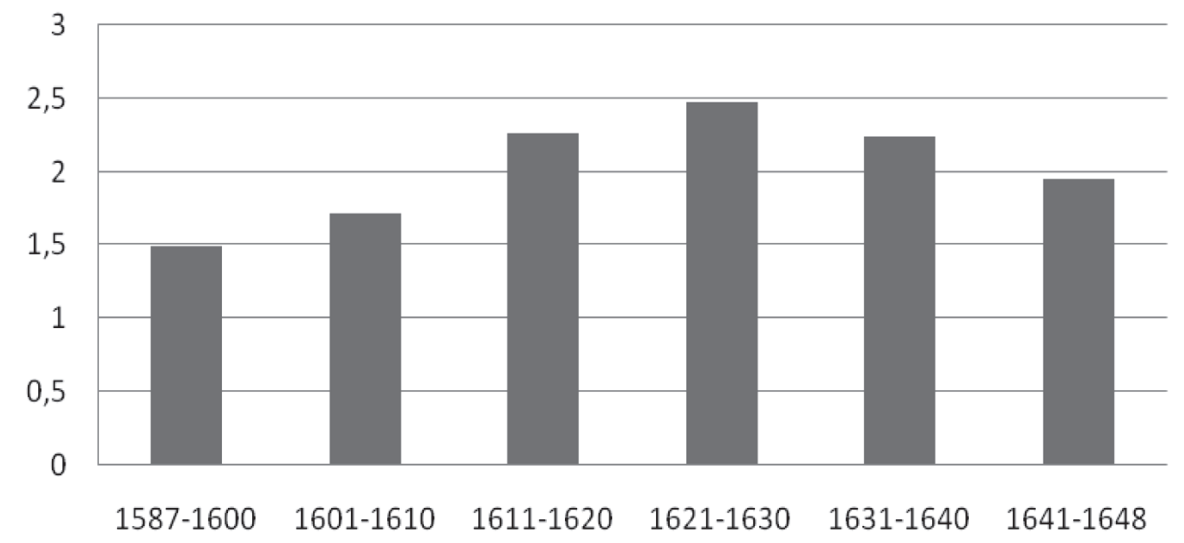

1,95 na stronę w latach 40. XVII w. Pewnym wytłumaczeniem tego faktu może być - wspomniane już - wydłużanie się instrukcji (por. Tabela 2). Instrukcje stały się coraz bardziej rozbudowane, a tym samym rosła liczba poruszonych w nich spraw, nie tylko o zasięgu państwowym, ale przede wszystkim - lokalnych, czy indywidualnych petitów, w których pojęcia rzeczypospolitej siłą rzeczy używano rzadziej. Nie jest to wytłumaczenie wystarczające.

W latach 40. XVII w. mamy bowiem do czynienia z pewnym nasileniem spornych momentów pomiędzy Wielkim Księstwem Litewskim a Koroną. Do nich należy gwałtowna reakcja sejmików litewskich na oddanie Moskwie części powiatu starodubowskiego w trakcie wyznaczenia granicy. Sprawę tę w swoich instrukcjach poruszyły wszystkie sejmiki litewskie przed sejmami w latach 1645 i $1646^{11}$. Do innych kwestii należały: konflikty kompetencyjne pomiędzy marszałkami litewskimi a koronnymi ${ }^{12}$,

${ }^{11}$ Instrukcje przed sejmem w roku 1645: brasławska: BPAN Kraków, rkps 365, k. 116; słonimska: BPAN Kraków, rkps 365, k. 120; nowogródzka: BCzart., 375, k. 849; grodzieńska: BPAN Kr, rkps 365, k. 122; mińska: BPAN Kr, rkps 360; instrukcje przed sejmem w roku 1646: słonimska: BPAN Kraków, rkps 365, k. 160; wileńska: BCzart., TN 140, nr 61, k. 227; żmudzka: BCzart., 378, nr 82, k. 443-444; brasławska: BCzart., TN 140, nr 59, k. 203; grodzieńska: BCzart., TN 140, nr 60, k. 211; lidzka: BPAN Kraków, rkps 365, k. 155; mińska: BPAN Kraków, rkps 365, k. 132-133; smoleńska: BCzart., TN 126, k. 1; trocka: BCzart., TN 140, nr 55, k. 175; wołkowyska: BCzart., TN 126, nr 7, k. 33.

${ }^{12}$ Poruszona w instrukcjach przed sejmem w 1645 r.: brasławskiej: BPAN Kraków, rkps 365, k. 117; grodzieńskiej: BPAN Kraków, rkps 365, k. 123; mińskiej: BPAN Kraków, rkps 360, k. 481; słonimskiej: BPAN Kraków, rkps 365, k. 120; w mniejszym zakresie poruszona także w instrukcjach przed sejmem w 1646 r.: wileńskiej: BCzart., TN 140, nr. 61, k. 242-243; grodzieńskiej: BCzart., TN 140, nr. 61, k. 242-243. 
pozywanie Litwinów przed sądy koronne ${ }^{13}$ czy choćby rozdział gospód na sejmie $^{14}$.

Przechodząc do rozważań dotyczących znaczenia terminu rzeczpospoli$t a \mathrm{w}$ litewskich instrukcjach sejmikowych, należy jeszcze raz podkreślić ich typologiczny i egzemplifikacyjny charakter. Ze wszystkich użyć tego pojęcia wybrano te, które dają się jednoznacznie przyporządkować do danej kategorii znaczeniowej. Wskażmy zatem najbardziej charakterystyczne ujęcia.

A. Rzeczpospolita jako państwo (w tym państwo polsko-litewskie)

Jest to znaczenie pojawiające się najczęściej (287 użyć), co zgadza się z podobną obserwacją E. Bem-Wiśniewskiej ${ }^{15}$. Przyporządkowano tu m.in. następujące zwroty: granice Rzeczypospolitej, dobra Rzeczypospolitej, skarb Rzeczypospolitej.

W obrębie tego znaczenia możemy wyróżnić podkategorię państwo w ogóle, spotykaną w przebadanych instrukcjach 12 razy. Przykładowo:

- a iż $w$ każdey Rzeczypospolitej prawami y wolnościami warowaney wszyscy legislatorowie otym naypierwiey stanowili, iakoby uczyniwszy domowemu pokojowi dosyć postronnym odpór obmyśliwali, tak y w tey Rzeczypospolitey [tu zaś w wyraźny sposób użyto terminu Rzeczpospolita już w znaczeniu państwa polsko-litewskiego] Oyczyźnie naszey nic nie schodziło, aby wprzód o pokoju domowym, potym o niebespieczenstwach postronnych konsultaty czynic ${ }^{16}$;

- szlachta nowogródzka w $1626 \mathrm{r}$. żaliła się na niebespieczeństwa [...] takowe niemal wszystkie, które potężne Rzeczy Pospolite mieszać i gubić zwykli ${ }^{17}$;

- ten sam sejmik w roku 1637 pisał: byliśmy tey nadziei, że za łaska Boża, którą szczęśliwie wszytkie Rzeczypospolite stoja ${ }^{18}$.

${ }^{13}$ Instrukcja nowogródzka z 1641 r.: BCzart., 375, k. 605; instrukcje przed sejmem z 1645 r.: brasławska: BPAN Kraków, rkps 365, k. 117; grodzieńska: BPAN Kraków, rkps 365, k. 124; mińska: BPAN Kraków, rkps 360, k. 482; nowogródzka: BCzart., 375, k. 852-853; słonimska: BPAN Kraków, rkps 365, k. 120; instrukcje przed sejmem z 1646 r.: grodzieńska: BCzart., TN 140, nr 60, k. 221; lidzka: BPAN Kraków, rkps 365, k. 158; instrukcja lidzka z 1647 r.: BPAN Kraków, rkps 365, k. 174.

${ }^{14}$ Instrukcje przed sejmem w 1641 r.: wileńska: AGAD, AR II 1202, k. 5; nowogródzka: BCzart., 375, k. 607; instrukcja kowieńska z 1643 r.: AGAD, AR II 1205, k. 6; instrukcje przed sejmem w 1645 r.: grodzieńska: BPAN Kraków, rkps 365, k. 124; nowogródzka: BCzart., 375, k. 854; instrukcje przed sejmem w 1646 r.: wileńska: BCzart., TN $140 \mathrm{nr}$ 61, k. 240; grodzieńska: BCzart., TN 140, nr 60, k. 216-217.

${ }^{15}$ Choć, jeszcze raz zaznaczmy, dokonaną w stosunku do nieco zmodyfikowanego znaczenia, tj. rzeczpospolita jako państwo polsko-litewskie; por. E. Bem-Wiśniewska, Funkcjonowanie..., s. 169.

${ }^{16}$ Instrukcja oszmiańska 1611, BPAN Kraków, rkps 365, k. 38; ta sama instrukcja, jednak bez początku także w AGAD AR II, 560.

${ }^{17}$ AGAD AR II, 963, k. 1.

${ }^{18}$ Biblioteka Czartoryskich (dalej: BCzart.), 375, k. 635. 
Znacznie częściej jednak termin ten ulega konkretyzacji i zawężony jest do państwa polsko-litewskiego. Tu przytoczyć można następujące przykłady:

- szlachta powiatu lidzkiego w 1598 r. zalecała podziękowanie królowi, iż staraniem swym Pańskim obmyśliwać raczy o tei R[zeczy] P [ospolitej] Oicziźnie naszei w tem wielkim niebezpieczeństwie zachodzacym od cesarza tureckiego ${ }^{19}$;

- w 1615 r. szlachta kowieńska postulowała: o tureckich zamystach y dotrzymaniu pokoiu, także i z Moskwa aby iako z naliepszym pożytkiem R[zeczy] P[ospolitej] stanowili zlecamy ${ }^{20}$;

- szlachta wołkowyska w 1627 r. informowała, iż król w swojej instrukcji przedkladać raczy wielkie niebezpieczeństwa na R[zecz]P[ospoli]ta następuiace a między inszemi nabardziey od Gustawa X[ięcia] Sudermańskiego ${ }^{21}$;

- w 1646 r. szlachta powiatu grodzieńskiego postulowała składanie przysięgi przez commisye, które do rozgraniczenia dóbr szlacheckich [od] dóbr Rzeczypospolitey od J[ego] K[rólewskiej] M[o]ści zesłani będą22.

Termin ten przynosi jednak znaczne wątpliwości interpretacyjne. Nierzadko trudno jest rozróżnić, w jakim stopniu konkretny jest desygnat pojęcia rzeczpospolita, tj. czy odnosi się on do państwa polsko-litewskiego, czy bardziej chodzi tu o desygnat abstrakcyjny, tj. państwo w ogóle (czy też dobra państwowe, skarb państwowy). Czasami wątpliwości te pozwala rozwiązać kontekst; za przykład niech posłużą wyżej wymienione postulaty sejmików lidzkiego z 1598 r., kowieńskiego z 1615 r. i wołkowyskiego z 1627 r. Wskazanie przez nie konkretnej, zagrożonej przez sąsiadów granicy państwa, pozwala jednoznacznie wywnioskować, że mamy do czynienia z rzecząospolitq w znaczeniu państwa polsko-litewskiego.

Niestety nie zawsze jesteśmy w tej szczęśliwej sytuacji. W wielu przypadkach równoprawne wydają się bowiem zarówno interpretacje typu granica państwa polsko-litewskiego, skarb państwa polsko-litewskiego, jak i granica państwa (w ogóle), granica państwowa oraz skarb państwowy (w ogóle). Co więcej, na tle zwrotu skarb rzeczypospolitej wskazać możemy jeszcze jeden poważny problem interpretacyjny. Nie funkcjonował wszak jeden skarb Rzeczypospolitej, a oddzielne skarby Korony i Wielkiego Księstwa Litewskie$\mathrm{go}^{23}$. Pojawia się więc pytanie, jak rozumieć użycie w tym kontekście terminu rzeczpospolita - czy jest to pewien skrót myślowy (a piszący te słowa mieli

${ }^{19}$ Archiwum Główne Akt Dawnych (dalej: AGAD), Archiwum Radziwiłłów (dalej: AR) II 354, k. 1 .

${ }^{20}$ AGAD, AR II, $621 \mathrm{k} .1$.

${ }^{21}$ AGAD, AR II, 981 k. 1.

${ }^{22}$ Biblioteka Polskiej Akademii Nauk w Krakowie (dalej: BPAN Kraków), rkps 365, k. 123.

${ }^{23}$ Szczegółowo: A. Filipczak-Kocur, Skarbowość Rzeczypospolitej 1587-1648. Projekty-ustawy - realizacja, Warszawa 2006. 
na myśli finanse państwa), czy mamy jednak do czynienia z użyciem terminu rzeczpospolita w znaczeniu Wielkiego Księstwa Litewskiego.

W związku z tym nasuwa się kolejne pytanie: czy skonkretyzowanym desygnatem terminu rzeczpospolita $\mathrm{w}$ znaczeniu państwo (pomijamy w tych rozważaniach desygnat abstrakcyjny - państwo w ogóle) będzie zawsze państwo polsko-litewskie, czy możliwe jest rozdzielenie go na części składowe wspólnego państwa polsko-litewskiego, tj. Koronę i Wielkie Księstwo Litewskie.

$\mathrm{Na}$ funkcjonowanie terminu Rzeczpospolita Księstwa Litewskiego lub Rzeczpospolita Litewska wskazali już w literaturze Henryk Wisner ${ }^{24}$ i Przemysław P. Romaniuk ${ }^{25}$. Pierwszy z autorów wskazał na rozpowszechnienie tych terminów w latach 60 . XVI w. ${ }^{26} \mathrm{~W}$ przebadanych instrukcjach sejmikowych termin rzeczpospolita właśnie w takim, ograniczonym do Litwy, znaczeniu pojawia się kilkukrotnie. W 1604 r. szlachta słonimska prosiła, aby król mieszkał w Wielkim Księstwie Litewskim tak dlia sprawiedliwości świętey, iako dlia porzadku i dlia ozdoby R[zeczy]P[ospolitey] W[ielkiego] X[ięs]tt[w]a Litewskiego, a także wysuwała prośbę skierowaną wobec senatorów Wielkiego Księstwa Litewskiego, aby przebywali przy królu dlia ozdoby maiestatu pańskiego i dlia potrzeb R[zeczy]P[ospolitej] W[ielkiego] X[ięstwa] Litewskie$g o^{27}$. Określenie Rzeczpospolita Wielkiego Księstwa Litewskiego pojawia się także w instrukcji wołkowyskiej z 1627 r., w której sejmik prosił o wsparcie dla odbudowy Birż, będących forteca dobra y bardzo potrzebna R[zecz]p[ospoli]tey W[ielkiego] X[ięstwa] L[itewskiego]. Ze względu na zawarte w tekście rękopisu skróty, niewykluczona jest także interpretacja $R$ [zecz]p[ospoli]tey [i] W[ielkiemu] X[ięstwu] L[itewskiemu] ${ }^{28}$. Poza tym, dane określenie spotykamy w instrukcjach wiłkomierskich z 1600 r. (o czym niżej) i 1639 r., w której sejmik domagał się: dygnitarstwa, urzędy, dobra R[zeczy]p [ospoli] tey X[ięstw] a Lit [ewskiego] aby wedlug praw dawnych rozdawane byty ${ }^{29}$.

$\mathrm{Z}$ drugiej strony, w instrukcji nowogródzkiej z 1646 r. spotykamy odwrotne zjawisko, zawężenie desygnatu terminu rzeczpospolita do Korony. Sejmik ten żądał, aby kwestia zapłaty wojsku kwarcianemu została uregulowana przez Koronę, motywując to: woysko kwarciane iż się na kredit Rzeczypospolitey Koronney zaciagnęto ${ }^{30}$.

Użycia te są jednak sporadyczne, co koresponduje z wnioskami P.P. Romaniuka, dotyczącymi co prawda przełomu XVII i XVIII w., według którego

${ }^{24}$ H. Wisner, op. cit., s. 17-29.

${ }^{25}$ P.P. Romaniuk, Pojęcie „Rzeczpospolita Litewska” w ruchu republikanckim na przełomie XVII i XVIII wieku, „Barok” 2006, z. 1 (25), 31-40.

${ }^{26} \mathrm{H}$. Wisner, op. cit., s. 17.

${ }^{27}$ BPAN Kraków, rkps 365, k. 14.

${ }^{28}$ AGAD, AR II 981, k. 4.

${ }^{29}$ RNB, awt. 133 , k. 50.

${ }^{30}$ BCzart., Teki Naruszewicza (dalej: TN) 140, nr 113, k. 431. 
termin Rzeczpospolita Litewska nie wszedł w Wielkim Księstwie Litewskim do powszechnego użycia ${ }^{31}$. Prawdopodobnie więc, używając terminu $r z e c z-$ pospolita $\mathrm{w}$ znaczeniu państwo, autorzy instrukcji mieli przede wszystkim na myśli państwo polsko-litewskie, a ze wskazanych tu zawiłości i problemów interpretacyjnych zapewne nie zdawali sobie sprawy. Prawdopodobna wydaje się też hipoteza, że pojęcie skarb rzeczypospolitej formułowane było jako skrót myślowy i nie oznaczało ono zawężenia znaczenia terminu rzeczpospolita do Wielkiego Księstwa Litewskiego.

B. Rzeczpospolita jako władza, czyli sejm Rzeczypospolitej, ale też określenie posłów

Jest to znaczenie stosunkowo często spotykane, w wykorzystanych instrukcjach wskazano 174 jego użycia. Warto więc przytoczyć przykłady:

- szlachta oszmiańska w 1607 r., ujmując się za prośbą plebana lebiedziewskiego, księdza Zawadzkiego, o 4 włóki na Mazowszu oraz za innymi, niewymienionymi osobami, polecała $u$ wszystkich stanów seymowi należacych z pilnościa prosić i starać się maia, żeby z taski J[eg]o Królewskiej M[o]ści z pozwoleniem wszystkiej Rzeczyp[ospoli]tey te prośby swe otrzymali ${ }^{32}$;

- sejmik witebski w 1615 r. prosił, aby potrzeby obronne zamku witebskiego Królowi Je[g]o M[oś]ci y Rzeczyp[ospoli]tey przełożyć33;

- sejmik połocki w 1632 r. (przed sejmem koronacyjnym) pisał: do spólney zgody wszystkiey Rz[eczy]p[ospoli]tey naszey Ich M[o]ść Panów Postów naszych odsyłamy ${ }^{34}$;

- sejmik miński w 1646 r., żądając zadośćuczynienia za oddanie Trubecka, nakazywał: przełożywszy to Panowie Posłowie nasi Królowi Je[g]o Mości y Statibus Reipubicae do żadney nie tylko konkluzji, propozycyi seymowey, ale ani namowy przystempować nie będq ${ }^{35}$.

Do wszelkich wniosków wysnutych na podstawie tych przykładów należy podchodzić ze szczególną ostrożnością. Warto jednak zauważyć, że w przypadku tego znaczenia liczba użyć (jeszcze raz podkreślmy - poddających się jednoznacznej interpretacji) w badanym okresie systematycznie wzrasta, o czym świadczą dane zawarte w Tabeli 4.

Dla bardziej przejrzystego ukazania tego zjawiska posłużymy się Wykresem 2, przedstawiającym użycie terminu rzeczpospolita w znaczeniu państwo (w tym państwo polsko-litewskie) oraz władza, sejm.

${ }^{31}$ P.P. Romaniuk, op. cit., s. 36; w tym zakresie uściślić należy więc wnioski H. Wisnera na temat funkcjonowania danego terminu (H. Wisner, op. cit., s. 17-18).

32 BPAN Kraków, rkps 365, k. 23.

${ }^{33}$ AGAD, AR II 637, k. 2.

${ }^{34}$ RNB, awt. 132, k. 15.

${ }^{35}$ BPAN Kraków, rkps 365, k. 132-133. 
Tabela 4. Użycie terminu Rzeczpospolita w znaczeniu władza, sejm w kolejnych latach

\begin{tabular}{c|c|c}
\hline Lata & Rzeczpospolita jako władza, sejm & $\begin{array}{c}\text { Rzeczpospolita jako wladza, sejm/ } \\
\text { instrukcję }\end{array}$ \\
\hline $1587-1600$ & 2 & 0,13 \\
\hline $1601-1610$ & 5 & 0,36 \\
\hline $1611-1620$ & 40 & 1,29 \\
\hline $1621-1630$ & 17 & 0,77 \\
\hline $1631-1640$ & 48 & 1,5 \\
\hline $1641-1648$ & 62 & 2,48 \\
\hline
\end{tabular}

Wykres 2. Liczba użyć terminu Rzeczpospolita w znaczeniu państwo i władza, sejm w przeliczeniu na instrukcję

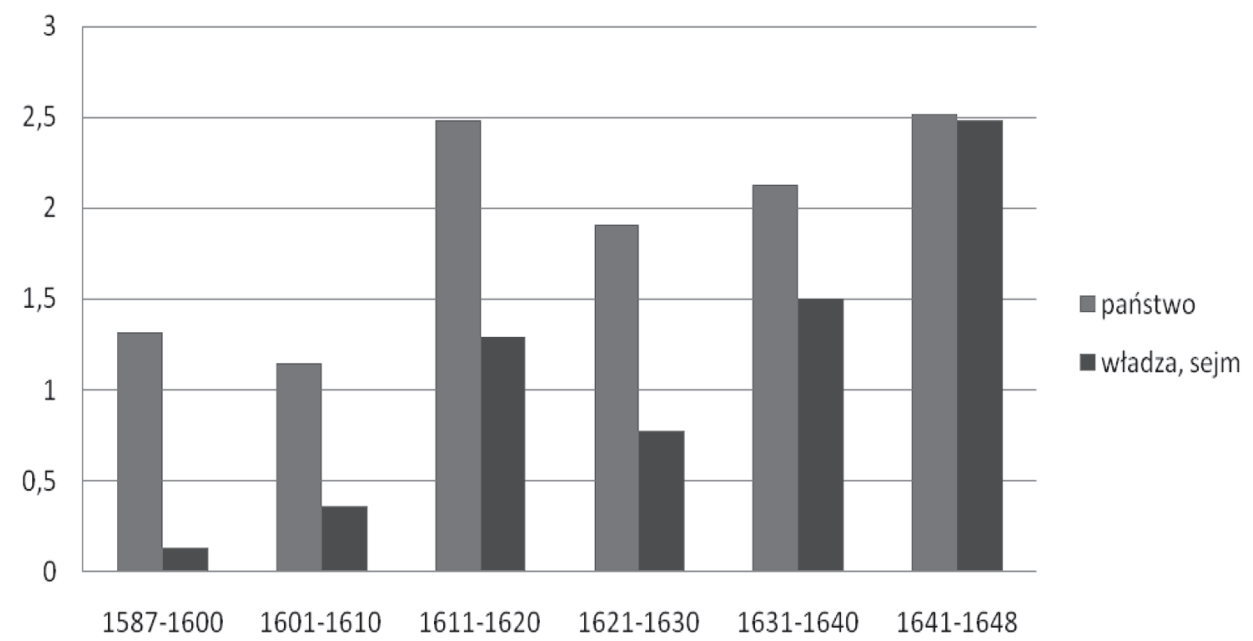

Poza wzrostem liczby użyć znaczenia władza, sejm można dostrzec, że frekwencja tego znaczenia w latach 1641-1648 jest porównywalna ze znaczeniem państwo polsko-litewskie.

C. Rzeczpospolita jako określenie szlachty, czyli wspólnoty

W odróżnieniu od badań E. Bem-Wiśniewskiej, tu na pierwszy rzut oka nie potwierdza się wniosek o bardzo licznym występowaniu takiego znaczenia ${ }^{36}$, gdyż na gruncie litewskich instrukcji sejmikowych udało się je jednoznacznie stwierdzić tylko 40 razy. Istota problemu leży jednak w przyjęciu założenia o zakwalifikowaniu do danej typologii jedynie jednoznacznych użyć terminu

\footnotetext{
${ }^{36}$ E. Bem-Wiśniewska, Funkcjonowanie..., s. 169.
} 
rzeczpospolita. W wielu przypadkach znaczenie szlachta, wspólnota jest bowiem jedną z możliwych (a często nawet najbardziej prawdopodobnych) interpretacji. Wypada zatem przyjąć możliwość jego częstszego występowania, niż wynika to $\mathrm{z}$ danych liczbowych zawartych w szkicu.

Dla zobrazowania użycia terminu rzeczpospolita w znaczeniu szlachta, wspólnota posłużmy się następującymi przykładami:

- w 1615 r. sejmik nowogrodzki, występując o nagrodę dla kasztelana wileńskiego Hieronima Chodkiewicza, pisał, że o jego zasługach w wojnie z Moskwą wiadomo dobrze wszytkiey R[zeczy]p [ospoli]tey ${ }^{37}$;

- szlachta mińska w roku 1625 pisała: żałosna nas wiadomość dochodzi, że Posłów, którzy za zleceniem od Braci affectatie R[zeczy]P[ospoli] tey donosza Ich M[ość] Panowie Senatorowie y Pieczętarze contuneliere tractuia, domagając się od nich, by na potym tak ostrymi responsami Ich M[o]śc[iów] Panów Postów y wszytkiey R[zeczy]P[ospoli]tei w osobach Ich M[ościów] nieznieważali ${ }^{38}$;

- ten sam sejmik w roku 1645 żalił się, iż R[zecz]p[ospoli]ta srodze coraz bywa nowemi aggrawowana exactiami ${ }^{39}$.

Należy jednakże zauważyć, że desygnatem znaczenia szlachta, wspólnota mogła być nie tylko szlachta Korony i Wielkiego Księstwa Litewskiego, ale szlachta tylko jednej z części składowych państwa. W 1600 r. sejmik miński domagał się przeznaczenia środków finansowych na obronę Litwy y to za wiadomościa i pozwoleniem wszey rzeczy pospolitey W[ielkiego]o X[ięstwa] Lit[ewskiego] ${ }^{40}$. W 1604 r. sejmik słonimski domagał się, aby podskarby skarbu W[ielkiego] X[ięstwa] L[itewskiego] pieniędzy bez wiadomości $R$ [zeczy]P[ospolitej] Litewskiei do Corony ni na nicz nie wydawa ${ }^{41}$. Ten sam sejmik w roku 1646 żalił się, że cło piławskie $z$ wielka szkoda Rzeczypospolitej X[ięstw] a Litt[ewskieg]o wybieraia ${ }^{42}$. Sejmik lidzki w 1616 r. prosił o interwencję w sprawie Andrzeja Montołta, pozwanego przed sąd koronny, co wszytkę R [zecz]p [ospoli]ta [...] obchodzi $i^{43}$. Chodzi tu niewątpliwie o szlachtę litewską, niejednokrotnie występującą w innych instrukcjach o niepozywanie Litwinów przed sądy koronne ${ }^{44}$.

${ }^{37}$ RNB, awt. 126, k. 5.

${ }^{38}$ AGAD, AR II 944, k. 4.

${ }^{39}$ BPAN Kraków, rkps 360, k. 481.

${ }^{40}$ RNB, awt. $130, \mathrm{k} .16$.

${ }^{41}$ BPAN Kraków, rkps 365, k. 14.

42 BCzart., TN 140, nr 57, k. 191; co ciekawe, inne kopie tej instrukcji nie zawierają tego sformułowania - BCzart., TN 126, nr 5, k. 26 zawiera z wielka szkoda obywatelów X[ięstw]a Lit$t$ [ewskieg]o, a BPAN Kraków, rkps 365, k. 160 z wielka szkoda X[ięstw]a Litt[ewskieg]o; możliwe więc, że jest to dodatek kopisty.

${ }^{43}$ AGAD, AR II 646a, k. 5.

${ }^{44}$ Warto zauważyć, że część określeń Rzeczpospolita Litewska, przytoczonych w pracy P.P. Romaniuka, należy rozumieć właśnie jako szlachta Wielkiego Księstwa Litewskiego; por. P.P. Romaniuk, op. cit., s. 34 . 
$\mathrm{Z}$ drugiej strony, sejmik grodzieński w $1628 \mathrm{r}$. domagał się wypłaty stu tysięcy złotych tytułem zadośćuczynienia za zamknięcie portu w Królewcu, gdyż to obiecat K[ról] Je[g]o M[oś]ć z skarbu coronnego y R[zecz]p[ospoli] ta Coronna, co per diploma iest assecurowano ${ }^{45}$.

Co więcej, znaczenie szlachta, wspólnota mogło zostać jeszcze bardziej zawężone - do szlachty danego powiatu. Dwie tego typu wypowiedzi spotykamy w końcu XVI w. W 1587 r. szlachta żmudzka, domagając się korzystania z puszcz żmudzkich przez wszystkich obywateli księstwa żmudzkiego, żaliła się, iż nakładanie jakichkolwiek ograniczeń w tej mierze ku kriwde i szkode reczypospolitoje est ${ }^{46}$. Sejmik brzeski zaś w 1598 r. wystąpił o nadanie starostwa brzeskiego osiadłemu tam szlachcicowi, argumentując, iż na tym starostwie wszytkiey R[zeczy]P[ospolitej] wiele należy ${ }^{47}$. Trzeba jednak zauważyć, że tego typu zawężenia są jednak zjawiskiem raczej wyjątkowym i najczęściej pod terminem rzeczpospolita rozumiano ogół stanu szlacheckiego.

Analizę znaczenia terminu rzeczpospolita warto uzupełnić ciekawym spostrzeżeniem: w latach 1587-1620 systematycznie rośnie liczba użyć sformułowań Rzeczpospolita nasza i Rzeczpospolita ojczyzna nasza. W latach 1611-1620 obu tych zwrotów w przebadanych instrukcjach użyto aż 44 razy. Interesujące jest także to, że w następnych dziesięcioleciach spadła frekwencja tych sformułowań, którymi w latach 1641-1648 posłużono się już tylko sześciokrotnie. Tendencje te potwierdza także wskaźnik liczby użyć w przeliczeniu na instrukcję. Dane te przedstawiono w Tabeli 5.

Tabela 5. Użycie zwrotów Rzeczpospolita nasza i Rzeczpospolita ojczyzna nasza w kolejnych latach

\begin{tabular}{c|c|c|c|c}
\hline Lata & $\begin{array}{c}\text { Rzeczpospolita } \\
\text { nasza }\end{array}$ & $\begin{array}{c}\text { Rzeczpospolita } \\
\text { nasza } \\
\text { na instrukcję }\end{array}$ & $\begin{array}{c}\text { Rzeczpospolita } \\
\text { ojczyzna nasza }\end{array}$ & $\begin{array}{c}\text { Rzeczpospolita } \\
\text { ojczyzna nasza } \\
\text { na instrukcję }\end{array}$ \\
\hline $1587-1600$ & 10 & 0,625 & 2 & 0,125 \\
\hline $1601-1610$ & 3 & 0,21 & 9 & 0,64 \\
\hline $1611-1620$ & 18 & 0,58 & 26 & 0,84 \\
\hline $1621-1630$ & 8 & 0,36 & 7 & 0,32 \\
\hline $1631-1640$ & 16 & 0,5 & 10 & 0,31 \\
\hline $1641-1648$ & 4 & 0,16 & 2 & 0,08 \\
\hline Ogółem & 59 & 0,41 & 56 & 0,39 \\
\hline
\end{tabular}

Dla zobrazowania omawianych tendencji posłużmy się Wykresem 3.

\footnotetext{
${ }^{45}$ AGAD, AR II 990, k. 2.

${ }^{46}$ AGAD, AR II 196, k. 6.

${ }^{47}$ AGAD, AR II supl., 142, k. 1.
} 
Wykres 3. Użycie zwrotów Rzeczpospolita nasza i Rzeczpospolita ojczyzna nasza na instrukcję

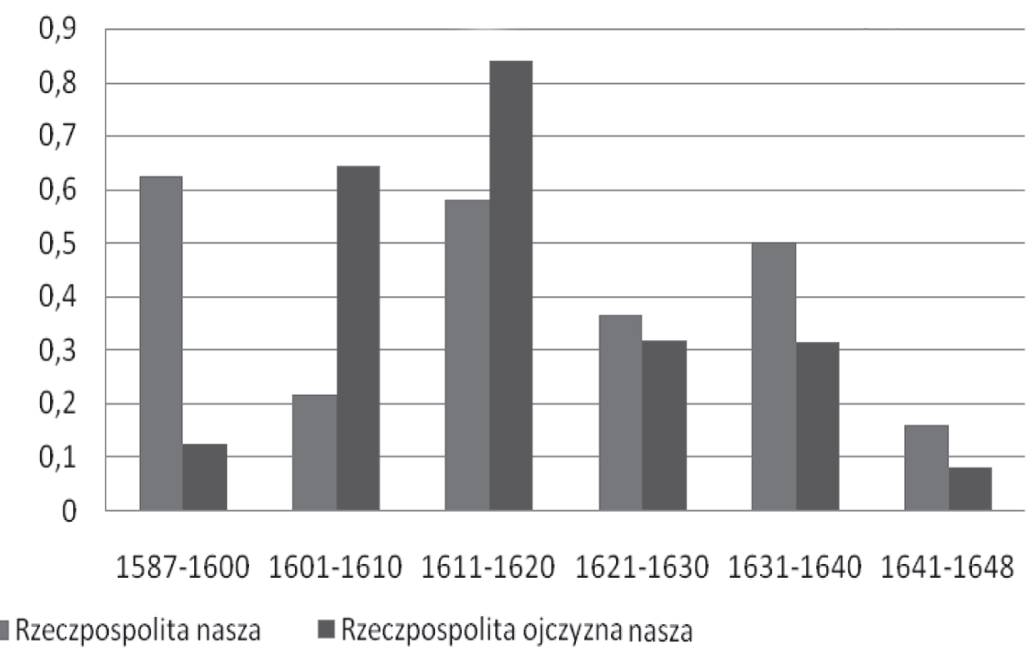

Użycie sformułowań typu Rzeczpospolita ojczyzna nasza sprawia, że warto zadać pytanie: jaki zakres terytorialny autorzy instrukcji obejmowali pojęciem ojczyzny? Innymi słowy: czy rozumieli oni pod nim całość Rzeczypospolitej Obojga Narodów, czy też jedynie Wielkie Księstwo Litewskie?

Niestety, na tak postawione pytanie nie da się udzielić jednoznacznej odpowiedzi. $Z$ jednej strony bowiem w litewskich instrukcjach sejmikowych znajdujemy przykłady objęcia terminem ojczyzna całości państwa polsko-litewskiego. Szlachta mińska w 1613 r. prosiła, aby znaleźć sposób na zniesienie skonfederowanych oddziałów, znoszac się y zgadzaiac $w$ tem paragrafie z Ich M[ościami] Pany Posty Coronnemi y W[ielkieg]o X[ięstw] a Lit[ewskieg]o, którzy zarówno z nami miluiac oiczyznę upatrować będa takowe śrzodki ${ }^{48}$. Sejmik słonimski w 1618 r. w kontekście zagrożenia tureckiego wyrażał wdzięczność królowi, że wielkimi zewszą oyczyznę otoczona niebezpieczeństwy oycowskim swym staraniem uspokajać raczy ${ }^{49}$. W tym samym roku sejmik wiłkomierski postulował uspokojenie sytuacji religijnej, aby w tey spólney oyczyźnie takowe uprzątnęty się urazy, kończąc jednocześnie instrukcję: co wszystko dawney Xiążat Ich M[oś]ci ku R[zeczy]p[ospoli]tey oyczyźnie naszey miłości poruczamy, pewni będąc po Ich M[oś]ciach, iż wszystko to, co ku spólney oyczyźnie dobremu będzie należało uczyniq ${ }^{50}$. Ten sam sejmik przed sejmem konwokacyjnym w 1632 r. żądał oddawania annat na obronę spólney oyczyzny ${ }^{51}$.

\footnotetext{
${ }^{48}$ AGAD, AR II 583, k. 3.

${ }^{49}$ BPAN Kraków, rkps 365, k. 84.

${ }^{50}$ AGAD, AR II 700, k. 5 i 8.

${ }^{51}$ AGAD, AR II 1150, k. 2.
} 
Z drugiej jednak strony można wskazać - choć rzadsze - przypadki użycia terminu ojczyzna w odniesieniu do Wielkiego Księstwa Litewskiego. Sejmik nowogródzki w 1639 r. żalił się na oddziały dokonujące spustoszeń w dobrach litewskich, dodając: jeśli to miała [..] ojczyzna cierpiećs ${ }^{52}$. Ten sam sejmik w 1641 r. pisał wprost: w oyczyźnie naszey, w X[ięs]twie Lit[ewskim ${ }^{53}$. W tym samym roku sejmik miński, nie zgadzając się na zapłatę podatków na zaopatrzenie Smoleńska i Dyneburga, argumentował: ciężki to zaprawde punct y propositia na oyczyznę nasza, że iednemu miastu przez miecz nabytemu ma Księstwo Litewskie tribut dawac ${ }^{54}$.

W wielu przypadkach dokładne określenie, czy pod pojęciem ojczyzna autorzy instrukcji rozumieli obie, czy tylko jedną z części składowych Rzeczypospolitej wydaje się niemożliwe, w innych - dopuszczalne są obie interpretacje. Pozostaje więc odnotować, że termin ten może oznaczać zarówno państwo polsko-litewskie, jak i Wielkie Księstwo Litewskie. Zauważmy jednak, że jednoznacznie dających się ująć przykładów pierwszego znaczenia można znaleźć w zbadanych instrukcjach znacznie więcej ${ }^{55}$.

Sformułowaną na wstępie niniejszych rozważań tezę, iż autorzy źródeł niekoniecznie zdawali sobie sprawę z niuansów znaczenia analizowanych terminów lub wręcz używali ich niekiedy w kilku znaczeniach jednocześnie, potwierdza przykład instrukcji witebskiej sprzed sejmu konwokacyjnego w roku 1632. Domagając się przekazania środków ze skarbu litewskiego na odbudowę zamku w Witebsku, autorzy instrukcji w jednym zdaniu użyli bowiem terminu rzeczpospolita w dwóch znaczeniach - jako sejm, władza oraz jako państwo polsko-litewskie. Instrukcja głosiła bowiem: prosić wszystkiey $R$ [zeczy]P[ospolitej] [tu w znaczeniu sejm, władza] na conwocatii zgromadzoney [...] aby sumę p[ie]n[ię]dzy s skarbu W[ielkieg]o X[ięstw] a Litt[ewskieg]o iako nayprędzey być może dali, gdyż forteca witebska iako snadnie każdy uważyć może wielka zasłona iest nie tylko W[ielkieg]o X[ięstw] a Litt[ewskieg]o, ale wszytkiey R[zeczy]P[ospoli]tey [w znaczeniu państwo polsko-litewskie $]^{56}$.

Interesujące są obserwacje poczynione w związku z proporcją liczby użyć terminów rzeczpospolita oraz odnoszących się do Wielkiego Księstwa Litewskiego i jego mieszkańców. Zanim przejdziemy do opisu zauważonych tu pra-

${ }^{52}$ AGAD, AR II 1177, k. 11.

${ }^{53}$ BCzart., 375, k. 610.

${ }^{54}$ AGAD, AR II, supl. 511, k. 3.

${ }^{55}$ Zob. E. Bem-Wiśniewska, Funkcjonowanie..., s. 170-171, o stosunku terminów ojczyzna i Polska: Innymi słowy, kiedy w tekstach staropolskich pojawia się określenie ,ojczyzna”, nie musi wcale odnosić się ono do „Polski”, lecz jego desygnatem najczęściej będzie właśnie Rzeczpospolita jako państwo polskie i litewskie. O wieloznaczności terminu ojczyzna w źródłach litewskich także H. Wisner, op. cit. 25-28; który twierdzi, że termin ten zaczęto odnosić do całości Rzeczypospolitej jeszcze przed doba rokoszu.

${ }^{56}$ RNB, awt. 132, k. 3. 
widłowości, przedstawmy wpierw ogólne dane dotyczące użycia tych ostatnich, zawarte w Tabeli $6^{57}$.

Tabela 6. Użycie terminów dotyczących WKL i jego mieszkańców w kolejnych latach

\begin{tabular}{c|c|c|c|c|c|c|c}
\hline Lata & WKL & $\begin{array}{c}\text { WKL } \\
\text { na stronę }\end{array}$ & Litwa & $\begin{array}{c}\text { Litwa } \\
\text { na stronę }\end{array}$ & Litwin & litewski & $\begin{array}{c}\text { litewski } \\
\text { na stronę }\end{array}$ \\
\hline $1587-1600$ & 110 & 1,53 & 10 & 0,12 & 6 & 28 & 0,41 \\
\hline $1601-1610$ & 68 & 0,96 & 12 & 0,12 & 2 & 18 & 0,28 \\
\hline $1611-1620$ & 193 & 1,19 & 8 & 0,05 & 0 & 12 & 0,09 \\
\hline $1621-1630$ & 139 & 1,42 & 2 & 0,02 & 0 & 3 & 0,03 \\
\hline $1631-1640$ & 221 & 1,33 & 4 & 0,03 & 1 & 12 & 0,14 \\
\hline $1641-1648$ & 260 & 1,45 & 5 & 0,03 & 0 & 19 & 0,1 \\
\hline Ogółem & 991 & 1,32 & 41 & 0,05 & 9 & 92 & 0,15 \\
\hline
\end{tabular}

Łączne użycie wszystkich wymienionych wyżej terminów ukazano w Tabeli 7 .

Tabela 7. Łączne użycie terminów dotyczących WKL i jego mieszkańców w kolejnych latach

\begin{tabular}{c|c|c}
\hline Lata & Lącznie & Lącznie na stronę \\
\hline $1587-1600$ & 154 & 2,14 \\
\hline $1601-1610$ & 100 & 1,36 \\
\hline $1611-1620$ & 213 & 1,34 \\
\hline $1621-1630$ & 144 & 1,46 \\
\hline $1631-1640$ & 238 & 1,51 \\
\hline $1641-1648$ & 284 & 1,58 \\
\hline Ogółem & 1133 & 1,53 \\
\hline
\end{tabular}

W celu zobrazowania uzyskanych wyników posłużono się Wykresem 4.

Terminy odnoszące się do Wielkiego Księstwa Litewskiego we wszystkich przebadanych instrukcjach występują łącznie 1133 razy, ustępując znacząco frekwencji terminu rzeczpospolita (1653 razy). Ze wszystkich tych terminów najczęściej, bo łącznie aż 991 razy, występują Wielkie Księstwo Litewskie i Księstwo Litewskie. Z ogólnej liczby 1133 użyć w 121 przypadkach zastosowano te terminy dla określenia urzędnika, np. hetman Wielkiego

${ }^{57} \mathrm{~W}$ poniższych tabelach i wykresach dla oznaczenia Wielkiego Księstwa Litewskiego posłużono się skrótem WKL. W kolumnie oznaczonej umownie Wielkie Księstwo Litewskie połączono dane dotyczące terminów Wielkie Księstwo Litewskie i Księstwo Litewskie). 
Wykres 4. Użycie terminów dotyczących Wielkiego Księstwa Litewskiego i jego mieszkańców w przeliczeniu na stronę w kolejnych latach

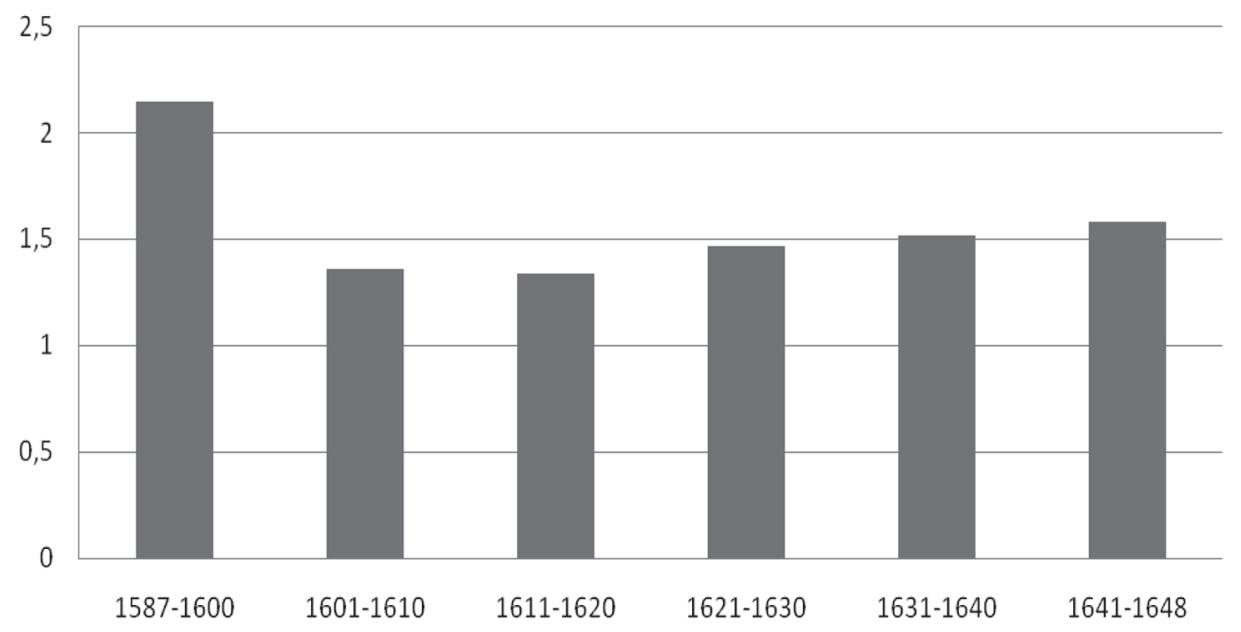

Księstwa Litewskiego, podczaszy Wielkiego Księstwa Litewskiego. Zauważmy też, że frekwencja tych terminów w latach $1587-1600$ jest dość wysoka $(2,14$ na stronę), ale w pierwszej połowie XVII w. znacząco spada, utrzymując się mniej więcej na stałym poziomie.

E. Bem-Wiśniewska, opisując znaczenie powyższych terminów, skoncentrowała się na 5 następujących:

- państwo litewskie;

- dzielnica, [...] czyli więcej niż „ziemia”, mniej niż „państwo”;

- ziemia;

- wspólnota [...] tyle, co „naród”, ,ludzie”;

- symbol $^{58}$.

Wypada zgodzić się z badaczką, iż dominującym znaczeniem jest dzielnica państwa polsko-litewskiego, zauważając jednocześnie, że na gruncie litewskich instrukcji sejmikowych nie potwierdza się częste użycie tych terminów w znaczeniu wspólnota, ludzie. Termin Litwin w przebadanych instrukcjach pojawia się jedynie 9 razy, ostatni raz w roku $1634^{59}$, zaś termin Litwa w znaczeniu ludzie jedynie 6 razy $^{60}$. Dla oddania znaczenia ludzie posługiwano się wyrażeniami naród litewski, obywatele Wielkiego Księstwa Litewskiego itp. Można pokusić się o hipotezę, że o ile autorzy koronni mogli dużo chętniej używać określenia Litwa dla oznaczenia mieszkańców Wielkiego Księstwa

${ }^{58}$ E. Bem-Wiśniewska, Funkcjonowanie..., s. 148-149.

${ }^{59}$ Instrukcja wiłkomierska 1634 r. (RNB, awt. 152, k. 145).

${ }^{60} \mathrm{~W}$ instrukcji wołkowyskiej z 1607 r. (AGAD, AR II, ks. 12, k. 336), mścisławskiej z $1615 \mathrm{r}$. (AGAD, AR II supl. 270, k. 2) i orszańskiej z 1617 r. (BCzart., 2245, nr 23, k. 157). 
Litewskiego, to sami Litwini woleli posługiwać się nieco bardziej „dostojnymi” określeniami (naród litewski).

$\mathrm{Na}$ gruncie litewskich instrukcji sejmikowych z lat 1587-1648 nie znajdują potwierdzenia spostrzeżenia E. Bem-Wiśniewskiej, jakoby autorzy pochodzący z Wielkiego Księstwa Litewskiego używali terminu Polska na oznaczenie Rzeczypospolitej ${ }^{61}$. W instrukcjach sejmikowych termin ten, po pierwsze, używany jest rzadko, raptem 16 razy, i szybko zanika na rzecz terminu Korona. Po drugie, zawsze w wyraźny sposób używany jest na określenie Korony. Przykładowo, sejmik oszmiański w 1598 r. pisał, że upominki tatarskie skarb Polski zastapić powinien za przyłaczeniem tych granic [województw wołyńskiego, bracławskiego i kijowskiego - przyp. autora] do Polski ${ }^{62}$, zaś sejmik połocki, występując w 1640 r. przeciw arendowaniu przez żydów ceł, myt i żup oraz prowadzeniu karczem, wskazywał, iż wiele województw y powiatów w Polszcze y Wielkim X[ię]stwie Litt[ewskim] sa y moga być bez nich ${ }^{63}$.

Zbadany materiał źródłowy przeczy też wnioskowi H. Wisnera co do przemiennego używania przez Litwinów terminów polski i litewski ${ }^{64}$. Sam przymiotnik polski pojawia się w zbadanych instrukcjach 25 razy. W znacznej części przypadków jest on częścią określenia król polski (królowie polscy). Dodatkowo, 34 razy występuje jako część określenia Korona Polska, a 6 razy jako część określenia Królestwo Polskie. Przytoczona przez autora instrukcja połocka z 1640 r., w której domagano się, aby budowniczy, horodniczy i wójt wileński bytt szlachcicem polskim osiadtym, a nie cudzoziemcem ${ }^{65}$ ma charakter wyjątkowy. Jako kontrprzykład można podać instrukcję wiłkomierską na sejm konwokacyjny w 1632 r., w której domagano się zabezpieczenia granic polskich i litewskich ${ }^{66}$, a więc potraktowano określenie polski jako synonim terminu koronny. Jeszcze w innym znaczeniu, na określenie całej szlachty Rzeczypospolitej, przymiotnika polski użyto w instrukcji nowogródzkiej z 1607 r., w której wymieniono wolną elekcję między inszemi wolnościami narodu polskie $[g] o^{67}$.

Nie podejmując się, tak jak w przypadku pojęcia rzeczpospolita, dokonania wyczerpującej klasyfikacji znaczeń, w których używane były terminy odnoszące się do Wielkiego Księstwa Litewskiego, warto jednak rozwinąć nieco rozważania na temat ich dzielnicowości. Wydaje się bowiem, że uwagi ta mają istotne znaczenie dla rozważań dotyczących stosunku autorów instrukcji do funkcjonowania Wielkiego Księstwa Litewskiego w ramach wspólnego państwa.

\footnotetext{
${ }^{61}$ E. Bem-Wiśniewska, Funkcjonowanie..., s. 107 i 114.

${ }^{62}$ AGAD, AR II 371, k. 2.

${ }^{63}$ AGAD, AR II 1197, k. 6.

${ }^{64} \mathrm{H}$. Wisner, op. cit., s. 21.

${ }^{65}$ AGAD, AR II 1197, k. 2.

${ }^{66}$ AGAD, AR II 1150, k. 2.

${ }^{67}$ BPAN Kraków, rkps 360, k. 198v.
} 
Na płaszczyźnie terminologii $\mathrm{w}$ instrukcjach sejmikowych dość rzadko mamy do czynienia z podkreśleniem elementów suwerenności Wielkiego Księstwa Litewskiego. Wspólny władca praktycznie zawsze nazwany jest królem, a nie wielkim księciem. Co ważniejsze, sięgając w swej argumentacji do przeszłości, nawet tej przedunijnej, autorzy instrukcji także wykorzystują tytuł królów polskich. Sejmik piński w roku 1607 domagał się oddalenia cudzoziemców, argumentując: dosyć Je[g]o Kró[lewskiej] M[ości] na narodzie tuteyszym, którzy przykładem przodków swych pierwszych Królom Polskim stużyli68. Sejmik oszmiański w roku 1641, pisał, iż dotychczasowymi regulacjami w sprawie dóbr stołowych wielka liczba królów polskich [...] się kontentowata ${ }^{69}$. Wyjątkiem jest tu pochodząca z $1618 \mathrm{r}$. instrukcja sejmiku nowogródzkiego, domagająca się rewizji i druku przywilejów Wielkiego Księstwa Litewskiego, nadanych przez Królów Ich M[oś]ci y Wielkich Książąt Litewskich Panów naszych ${ }^{70}$. Interesującego sformułowania użył natomiast w roku 1632 (przed sejmem konwokacyjnym) sejmik witebski, powołując się na przywileje wydane za przodków Ich Mości królów polskich y W[ielkieg]o X[ięstw] a Litt[ewskieg]o ${ }^{71}$.

Charakterystyczne jest także sposób użycia zwrotów Korona i Wielkie Księstwo Litewskie. Prawie zawsze na pierwszym miejscu wymieniona jest właśnie Korona. Oto kilka przykładów. Sejmik miński w 1613 r. prosił o wspólne narady z Pany posty Coronnemi y W[ielkiego]o X[ięstw] a Lit[ewskieg]o w sprawie zniesienia skonfederowanych oddziałów wojskowych ${ }^{72}$. Sejmik wiłkomierski w 1625 r. zalecał poparcie manifestacji na przeszłych dwu sejmach od Ich M[o]ści Panów Postów niektórych, tak coronnych, iako y W[ielkieg]o X[ięstw] a Lit[ewskieg]o ${ }^{73}$, natomiast sejmik brasławski w $1640 \mathrm{r}$. domagał się nienadawania nowych tytułów i pozostawienia tylko starych tytułów tak x[iąząt] Ich M[o]ści Corony Polskiey, iako y W[ielkieg]o X[ięstw] $a$ L[itewskieg] $o^{74}$. Wyjątkiem jest tu wspomniana już instrukcja nowogródzka z 1618 r., zawierająca prośbę, aby w sprawie napadów kozackich ze wszystkimi stany X[ięstw] a Litt[ewskieg]o y Coronnymi sposób y obronę namówici ${ }^{75}$.

Inne spostrzeżenie dotyczy takich wyrazów jak dobro, pożytek, łączących się przede wszystkich z terminem rzeczpospolita, szczególnie w dość

${ }^{68}$ BPAN Kraków, rkps 365, k. 35.

${ }^{69}$ AGAD AR II, 1201, k. 5.

${ }^{70}$ AGAD AR II, 701, k. 2.

${ }^{71}$ Interesująca jest także lista owych królów polskich i Wielkiego Księstwa Litewskiego, obejmująca zarówno wielkich książąt litewskich, którzy nie byli królami polskimi: Witolda i Zygmunta Kiejstutowicza (jedynie przy nim pojawia się tytuł wielkiego księcia), jak i królów polskich, nie będących wielkimi książętami: Władysława Warneńczyka i Jana Olbrachta; RNB, awt. 132, k. 5.

${ }^{72}$ AGAD, AR II 583, k. 3.

${ }^{73}$ AGAD, AR II 937, k. 2.

${ }^{74}$ AGAD, AR II 1192, k. 3.

${ }^{75}$ AGAD AR II, 701, k. 2. 
skonwencjonalizowanych prośbach o podziękowanie królowi czy końcowych formułach instrukcji. Przykładowo, sejmik orszański w 1596 r. pisał o zwołaniu sejmu dlia welikich $i$ ważnych potreb reczy pospolitoje ${ }^{76}$, sejmik miński w 1608 r. proponował, aby wespót z Ich M[oś] ciami Pany Posłami W [ielkieg] o X[ię]stwa Lit[ewskieg]o określić sposób służby rotmistrzów powiatowych, gotowych do stawienia się gdzie potrzeba R[zeczy]p[ospoli]tey okaże $e^{77}$, a szlachta lidzka w 1630 r. prosiła o podziękowanie królowi za obmyśliwanie okoto dobra R[zecz]p[ospoli]tey. W tej samej instrukcji spotykamy jednak wyjątek od opisanej tu prawidłowości, w sprawie zaciągów wojsk cesarskich szlachta lidzka domagała się bowiem: na to przypaść, co z nalepszym W[ielkieg]o X[ięstw] Lit[ewskiego] będzie ${ }^{78}$.

Warto zauważyć jeszcze jedną prawidłowość. W omawianym okresie stosunek liczby użyć terminów rzeczpospolita i terminów oznaczających Wielkie Księstwo Litewskie (potraktowanych łącznie) istotnie zmienił się na korzyść terminu rzeczpospolita. O ile w latach 1587-1600 znacząco przeważają określenia dotyczące Wielkiego Księstwa Litewskiego (61:39), to już w latach 1601-1610 odnotowujemy niewielką przewagę terminu rzeczpospolita (53:47). W następnych dziesięcioleciach przewaga ta osiąga istotne rozmiary (ponad 60\%), nieco spadając w latach 1641-1648 (57:43), co koresponduje ze spadkiem częstotliwości użycia terminu rzeczpospolita w tym okresie (por. Tabelę 3 i Wykres 1). Szczegółowe dane zamieszczono w Tabeli 8.

Tabela 8. Liczba użyć terminu rzeczpospolita i określeń Wielkiego Księstwa Litewskiego

\begin{tabular}{c|c|c}
\hline Lata & Liczba użyć terminu rzeczpospolita & $\begin{array}{c}\text { Liczba użyć } \\
\text { określeń WKL }\end{array}$ \\
\hline $1587-1600$ & 99 & 154 \\
\hline $1601-1610$ & 115 & 100 \\
\hline $1611-1620$ & 387 & 213 \\
\hline $1621-1630$ & 259 & 144 \\
\hline $1631-1640$ & 421 & 238 \\
\hline $1641-1648$ & 372 & 284 \\
\hline Ogółem & 1653 & 1133 \\
\hline
\end{tabular}

Wzajemny stosunek frekwencji tych terminów w kolejnych okresach przedstawiono na Wykresach 5-10.

\footnotetext{
${ }^{76}$ AGAD, AR II 346, k. 1.

${ }^{77}$ AGAD, AR II 545, k. 3.

${ }^{78}$ AGAD, AR II 1030, k. 1.
} 
Wykres 5. Stosunek użycia terminów $R P$ i $W K L$ w latach 1587-1600

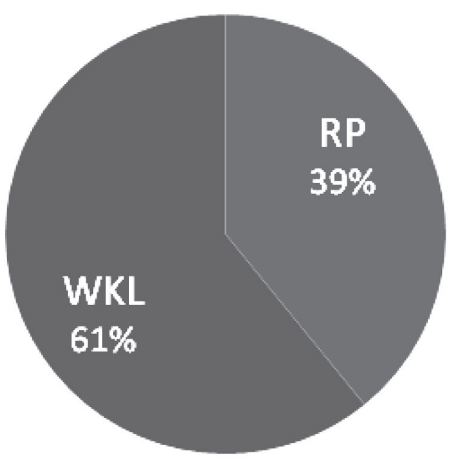

Wykres 7. Stosunek użycia terminów $R P$ i $W K L$ w latach 1611-1620

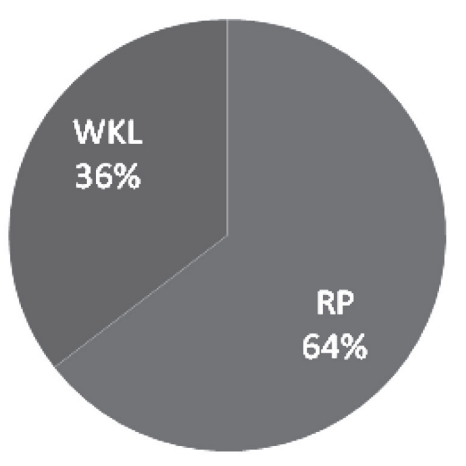

Wykres 9. Stosunek użycia terminów $R P$ i $W K L$ w latach 1631-1640

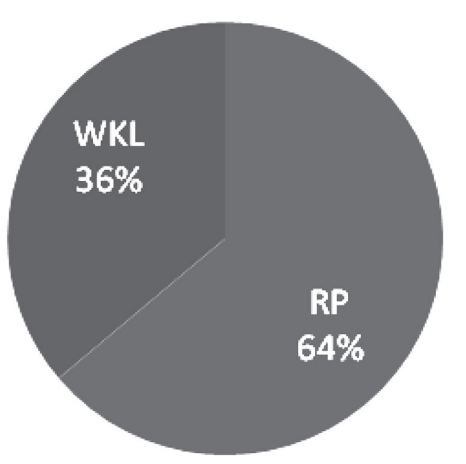

Wykres 6. Stosunek użycia terminów $R P$ i $W K L$ w latach 1601-1610

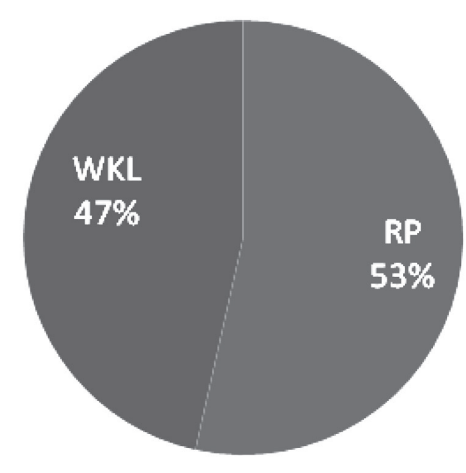

Wykres 8. Stosunek użycia terminów $R P$ i $W K L$ w latach 1621-1630

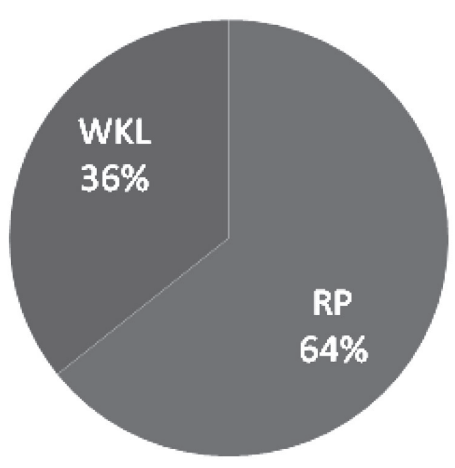

Wykres 10. Stosunek użycia terminów $R P$ i $W K L$ w latach 1641-1648

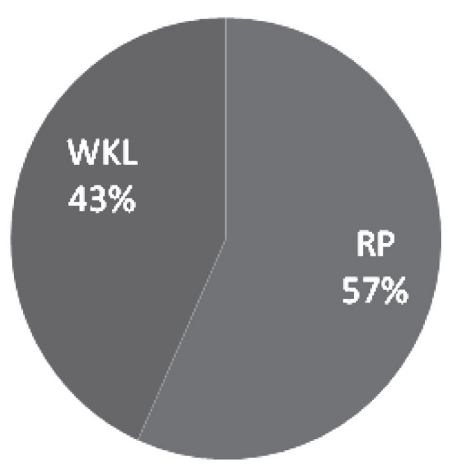


Podtrzymując poczynione wyżej uwagi dotyczące niejednoznaczności pojęcia rzeczpospolita, należy jednak zauważyć, że wskazana tu tendencja jest wyraźna.

Można się chyba pokusić o stwierdzenie, że w większości przypadków użycia pojęcia rzeczpospolita w znaczeniu państwo oraz szlachta mamy jednak do czynienia z rozumieniem go jako obejmującego ogót państwa polsko-litewskiego oraz ogół stanu szlacheckiego, a więc zarówno Koronę, jak i Wielkie Księstwo Litewskie. Ten sposób rozumienia terminu jest jeszcze wyraźniejszy w znaczeniu sejm, gdyż ustrój parlamentarny Rzeczypospolitej Obojga Narodów zasadzał się na jedności - jej przejawem jest wszak zarówno sama instytucja wspólnego sejmu, łączącego wszystkie stany sejmowe i obie części Rzeczypospolitej, jak i sposób jego działania, dla podjęcia jakichkolwiek decyzji wymagający wspólnej zgody trzech stanów i wszystkich ich przedstawicieli (nie tylko koronnych i litewskich, ale w rozumieniu znacznie szerszym - wszystkich województw, ziem i powiatów, przedstawicieli całego narodu szlacheckiego). W terminie rzeczpospolita zawarty jest więc pewien walor wspólnotowy, nawet jeśli nie zawsze obejmuje on całość państwa polsko-litewskiego i ogół szlachty.

Co więcej, uwzględniając w kontekście wskazanych wyżej przemian stosunku liczby użyć terminów rzeczpospolita i Wielkie Księstwo Litewskie określenia Wielkie Księstwo Litewskie i Korona oraz nazwy urzędników (typu hetman Wielkiego Księstwa Litewskiego), można się pokusić o wniosek, iż $\mathrm{w}$ omawianym okresie w retoryce instrukcji sejmikowych owa zaznaczona tu wspólnotowość zaczyna przeważać nad elementami partykularyzmu.

Należy wreszcie omówić wspomnianą na wstępie instrukcję wiłkomierską z 1600 roku $^{79}$. Jest ona wyjątkowa na tle innych, zarówno ze względu na swoją długość (14 stron rękopisu, drobnym pismem), jak i częstotliwość użycia oraz znaczenia pojęć będących przedmiotem analizy. W tekście owej instrukcji aż 72 razy wykorzystano termin rzeczpospolita, w tym 26 razy zwrot rzeczpospolita nasza, a także 44 razy użyto określeń Wielkie Księstwo Litewskie i litewski. Ze względu na to, że tak duże wartości liczbowe w znacznym stopniu zmieniłyby otrzymane wyniki, przy czym zmiany te byłyby wywołane jedynie na podstawie jednego, nieproporcjonalnie bogatego źródła, zdecydowano się na wyłączenie tej instrukcji spoza obliczeń statystycznych.

Obawa o zniekształcenie otrzymanych wyników nie jest jednak jedynym powodem tej decyzji. Przemawia za nią także znaczna różnica w rozumieniu wskazanych terminów przez autorów instrukcji. Nieporównywalnie częściej niż w innych źródłach, terminu rzeczpospolita użyto bowiem na określenie Wielkiego Księstwa Litewskiego lub szlachty litewskiej. Przykładowo, pisząc o zagrożeniu szwedzkim, wyrażono przekonanie, że niebespieczeństwa ziemi

${ }^{79}$ RNB, awt. 133, k. 121-127. 
inflanckiey [...] zachodza wszystkę R[zecz]P[ospolita] W[ielkieg]o X[ięstw] a Litt[ewskieg]o y Coronę Polska. Użyty tu termin rzeczpospolita można interpretować jako państwo, ale zawężone do Wielkiego Księstwa Litewskiego, lub jako szlachtę Wielkiego Księstwa Litewskiego, której odpowiednikiem byłaby w tym wypadku szlachta koronna (jak należałoby wtedy interpretować termin Korona Polska).

$\mathrm{W}$ innym miejscu, domagając się ujęcia się za prawosławnym bractwem wileńskim, będącym przedmiotem ataków ze strony studentów Akademii Wileńskiej, sejmik uzasadniał swoje żądanie tym, że tho zachodzi y o wielkie niebespieczeństwo przywodzi wszytke R[zecz]P[ospolita] naszę W[ielkiego] X[ięstwa] Lit[ewskiego] (w znaczeniu wspólnota, stan szlachecki, ograniczonym jednak do szlachty Wielkiego Księstwa Litewskiego). Charakterystyczne jest kilkukrotne wykorzystanie przez autorów instrukcji (poza nią spotykanego jedynie sporadycznie) zwrotu rzeczpospolita Wielkiego Księstwa Litewskiego, a także dokonane przez nich ograniczenie desygnatu terminu rzeczpospolita do Wielkiego Księstwa Litewskiego lub szlachty litewskiej. Paradoksalnie choć czysto statystyczne dane na pierwszy rzut oka powinny temu przeczyć, w pewnym stopniu potwierdza to wniosek o postępującej ewolucji terminologii instrukcji sejmikowych w kierunku wymiaru wspólnotowego, wychodzącego poza elementy partykularne.

Podsumowując rozważania, należy zwrócić uwagę na dynamiczny charakter omawianych zjawisk. W końcu XVI w. na płaszczyźnie używanej w litewskich instrukcjach sejmikowych terminologii dominuje jeszcze spojrzenie z własnego, litewskiego punktu widzenia. W wieku XVII mamy jednak do czynienia z wyraźnym preferowaniem terminu rzeczpospolita i dawaniem wyrazu wspólnotowemu charakterowi państwa polsko-litewskiego. Świadczy o tym zarówno wzrost frekwencji terminu rzeczpospolita, jak i zmiana stosunku liczby użyć tego terminu w stosunku do nazw odnoszących się do Wielkiego Księstwa Litewskiego. Potwierdzeniem tej tendencji jest także wyraźny wzrost frekwencji sformułowań Rzeczpospolita nasza i Rzeczpospolita ojczyzna nasza.

W dynamice przemian dotyczących badanych terminów zwracają uwagę dwa momenty. Pierwszym z nich jest szczególnie wysoka frekwencja zwrotów Rzeczpospolita nasza i Rzeczpospolita ojczyzna nasza w drugim dziesięcioleciu XVII w. Drugim - znaczący spadek ich użycia, a także użycia terminu rzeczpospolita w latach 40. XVII w., które na płaszczyźnie terminologii instrukcji wypada nazwać okresem pewnego „kryzysu” w stosunku do związku z Koroną.

Pewnym wyjaśnieniem pierwszego zjawiska może być wojna z Moskwą w 1. 1609-1618. W litewskich instrukcjach sejmikowych z tego okresu znajdujemy bowiem liczne wezwania do współpracy Korony i Wielkiego Księstwa Litewskiego. W swojej retoryce sejmiki odwoływały się do poczucia jedno- 
ści Rzeczypospolitej. Przykładowo, sejmik kowieński w 1615 r. domagał się wsparcia pieniężnego ze strony Koroniarzy: aby też y stany coronne iako bracia jedney oyczyzny do tegoż przystąili y równo z nami tychże ciężarów nosić pomogli ${ }^{80}$. Sejmik wiłkomierski w $1618 \mathrm{r}$. wyraził natomiast poparcie dla wyprawy królewicza Władysława, który przeszłe lato na posłudze R[zeczy] p [ospoli]tey spólney oyczyzny na dalsze dla uspokoienia od Moskwy niebezpieczeństwa udać się raczyt ${ }^{81}$.

Jeśli przyjąć założenie, że na postawę sejmików litewskich w znacznym stopniu wpływało zagrożenie zewnętrzne, należy odpowiedzieć na pytanie, dlaczego w latach 1621-1630-pomimo prowadzenia wojny ze Szwecją - obserwujemy spadek częstotliwości użycia określeń Rzeczpospolita nasza i Rzeczpospolita ojczyzna nasza. Zauważmy, że instrukcje na sejmy z lat 1621-24 są nam przeważnie nieznane. Przeniesienie zaś w 1626 r. głównego ciężaru działań wojennych na teren Prus, a także litewskie pretensje o niedostateczne finansowanie przez Koronę działań w Inflantach mogły zadecydować o mniejszym zapotrzebowaniu na odwoływanie się w retoryce instrukcji do poczucia jedności wspólnej ojczyzny.

Lata 40. XVII w. są natomiast, jak wskazano wcześniej, okresem nasilenia litewskich pretensji wobec Koroniarzy, związanych z przekazaniem Moskwie części powiatu starodubowskiego wraz z Trubeckiem, konfliktami kompetencyjnymi marszałków koronnych i litewskich oraz pozywaniem Litwinów przed sądy koronne.

Jeszcze raz podkreślając niereprezentatywność instrukcji sejmikowych w stosunku do ogółu źródeł epoki, pozwólmy jednak wyrazić wątpliwość, czy nie należałoby nieco inaczej spojrzeć na posiadające bogatą literaturę pojęcie partykularyzmu litewskiego (nie zaprzeczając bynajmniej istnieniu tego zjawiska) i rozpatrywać je w szerszym kontekście wzajemnych stosunków polsko-litewskich, w których element współpracy, choć może mniej uchwytny źródłowo, często wydaje się niedoceniany.

${ }^{80}$ AGAD, AR II 621, k. 3.

${ }^{81}$ AGAD, AR II 700, k. 3. 